\title{
Starch edible coating of papaya: effect on sensory characteristics
}

\author{
Revestimento de mamão papaia por películas de amido: efeito nas características sensoriais
}

\author{
Ariane CASTRICINI ${ }^{1}$, Regina Celi Cavestré CONEGLIAN ${ }^{2 *}$, Rosires DELIZA ${ }^{3}$
}

\begin{abstract}
The coating of papayas with Cassava Starch (CS) and carboxymethyl starch (CMS) is an alternative to extend the shelf life of these fruits. This study evaluated the effect of the three different levels of CS and CMS (1,3, and 5\%) on sensory characteristics of papayas during storage. Nine selected and trained assessors evaluated 13 sensory attributes using the Multiple Comparison Test. The appearance and flavor attributes of the papayas treated with CS and CMS were compared to the control or reference sample (R - fruit without coating) using a nine-point scale, which varied from 1: less intense than R; 5: equal to R; 9: more intense than $\mathrm{R}$. The samples were coded with three digit numbers and evaluated with repetition by a panel of assessors. In general, appearance was more affected by the coatings than flavor. Fruits coated with 3 and $5 \%$ of both coatings kept the green color longer than the other coating's concentrations, and at 5\% the color of the fruits was less uniform on the last evaluation day. The 3 and 5\% CS coating gave greater brightness to the fruits. 5\% CMS favored the presence of fungi and damaged the fruit surface at the $14^{\text {th }}$ day of storage. The CS coating at 5\% presented peeled surface during all experimental time. Changes in fruits' flavor were perceived at the $12^{\text {th }}$ and $14^{\text {th }}$ days of storage. A less characteristic flavor and a bitter taste were noticed in the fruits coated with CS and CMS at $5 \%$ at the $12^{\text {th }}$ day of storage.
\end{abstract}

Keywords: Carica papaya L.; cassava starch; modified starch; sensory evaluation.

\section{Resumo}

O revestimento de mamões por Fécula de Mandioca (FM) e carboximetilamido (CMA) é uma alternativa que visa prolongar a vida de prateleira dos frutos. Este estudo avaliou o efeito de três diferentes níveis de FM e CMA (1, 3 e 5\%) nas características sensoriais de mamão papaia durante o armazenamento. Nove provadores selecionados e treinados avaliaram 13 atributos sensoriais através do teste de comparação múltipla. Os atributos de aparência e sabor dos mamões tratados com FM e CMA foram comparados com a referência (R - sem revestimento) usando escalas de nove pontos, as quais variaram de 1: menos intenso que R; 5: igual a R; 9: mais intenso que R. As amostras foram codificadas com número de três dígitos e avaliadas com repetição pelos provadores. Em geral, a aparência dos frutos foi mais afetada que o sabor pelos revestimentos utilizados. Frutos revestidos a 3 e 5\% de FM e CMA apresentaram coloração verde por mais tempo, mas a 5\% a cor foi menos uniforme no último dia de avaliação. Os revestimentos de FM a 3 e 5\% conferiram maior brilho aos frutos. O CMA a 5\% favoreceu a presença de fungos e injúrias na superfície no $14^{\circ}$ dia de armazenamento. O revestimento de FM a 5\% apresentou descascamento durante todo o período experimental. Alterações no sabor dos frutos foram percebidas aos $12^{\circ}$ e $14^{\circ}$ dias de armazenamento. Sabor menos característico e gosto amargo foram identificados nos frutos revestidos por FM e CMA a 5\% no $12^{\circ}$ dia de armazenamento.

Palavras-chave: Carica papaya L.; fécula de mandioca; amido modificado; avaliação sensorial.

\section{Introduction}

Brazil produces annually $1.900 .000 \mathrm{t}$ of papaya in 36750 ha of land. In 2009, it was the second largest exporter of fruits $(27.554 \mathrm{t})$. Bahia and Espírito Santo are the Brazilian States with the highest national production with 902,525 and $630,124 \mathrm{t}$, respectively (AGRIANUAL..., 2011).

Papaya is a climacteric fruit characterized by an increase in the respiratory rate, an autocatalytic production of ethylene, and sensory alterations such as color, flavor, and softening during ripening. Several studies have aimed to investigate the extension of the shelf life of papaya considering that it perishes after harvest, and some of them focused on the application of Modified Atmosphere (MA). This technique was used in beets (ARRUDA et al., 2004), formosa papaya (PEREIRA et al., 2006), cucumbers (REIS et al., 2006), grapes (FAKHOURI et al., 2007), (HOA; DUCAMP, 2008), and minimally processed pear (BOTREL et al., 2010) with satisfactory results. The effects of MA can be achieved using Cassava Starch coatings (CS) and modified starch Carboxymethyl (CMS), which are natural and nontoxic products and can be consumed together with the fruit without causing any food poisoning problems (HENRIQUE; EVANGELISTA, 2006). CMS arouses interest since it achieves maximum viscosity without the need of heating. Henrique (2002) reported CMS coatings of low and high viscosity at 3 and $5 \%$ as those which have the best characteristics for use

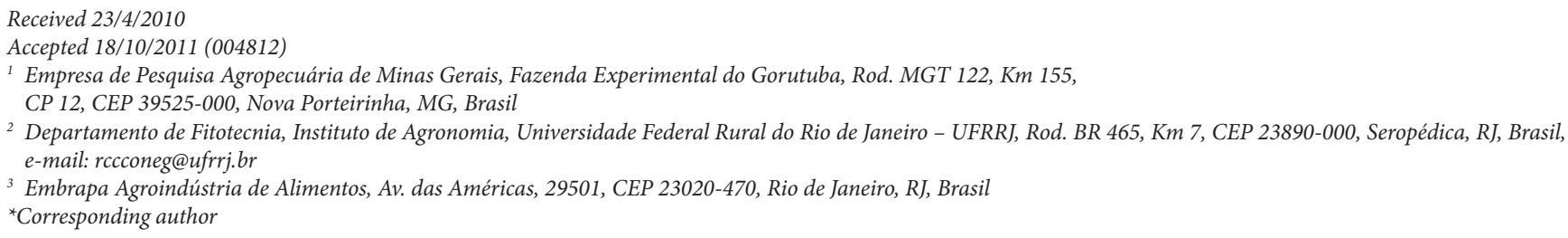


in postharvest operations of horticulture products although they presented high permeability in relation to the PVC film. Therefore, modifications in the formulation were suggested by the author.

The sweet taste of papaya together with changes in color and texture are quality characteristics valued by consumers, which can be evaluated using sensory analysis (OLIVEIRA JÚNIOR; COELHO; COELHO, 2006). The aim of this study was to investigate the effects of coatings of Cassava Starch (CS) and carboxymethyl starch (CMS) on sensory characteristics of papaya during storage.

\section{Material and methods}

Papayas (Carica papaya L.) from Solo group, Golden cultivar, were used after having been harvested at the preclimacteric stage ("nearly ripe"), with green color, although physiologically developed. They were grown in a commercial orchard located in Linhares - ES. Transportation to the city of Rio de Janeiro was done using a refrigerated truck $\left(12{ }^{\circ} \mathrm{C}\right)$ in order to preserve the stage of ripening at which the fruits were harvested. However, the fruits were selected for standardization regarding the degree of maturation before the treatments.

Three different levels (1,3, and 5\%) of cassava starch (CS, a native starch) and carboxymethyl starch (CMS, named FLEXAMID ${ }^{\circ}$ ) were used to coat five fruits of each treatment. In addition, a reference sample (fruits without coating), which had only been immersed in distilled water, was considered the seventh treatment. The appearance and flavor attributes were evaluated in several sessions, and a total of 112 fruits were used.

The cassava formulations were obtained by heating at $70^{\circ} \mathrm{C}$ under stirring in distilled water up to gel formation, and after this procedure they were left at rest at room temperature for cooling. The fruits were immersed in the suspensions and placed on nylon netting for drying (HENRIQUE, 1999). Formulations of carboxymethyl starch were obtained through dispersion of the carboxymethyl starch of high viscosity in distilled water with constant stirring at room temperature. The solutions were left to rest for approximately 12 hours for the withdrawal of bubbles before the application of the coating treatment. The coated fruits were stored at $20 \pm 2{ }^{\circ} \mathrm{C}$ (mean of $20.2^{\circ} \mathrm{C}$ ) for 14 days after the application.

\subsection{Sensory evaluation}

Nine selected and trained assessors evaluated the fruits submitted to the different treatments during 14 days of storage by comparing them with the control or reference sample (fruits without coating) in terms of sensory attributes. The study consisted of several steps, which are described below:

- Generation of sensory attributes - fruits with distinct coatings and which were stored for different periods were used in this stage in order to create great diversity for appearance, and therefore to make possible that sensory attributes were generated and used for describing the papayas in terms of sensory characteristics. Four sessions were conducted to identify the attributes of appearance and flavor. The fruits were presented in trays displayed on a table surrounded by the entire sensory panel;

- Definition of the sensory attributes and panel training after generating the attributes, the sensory panel identified and consensually defined the terms which best described the fruits. Next, the training sessions were carried out for eight weeks so that the sensory panel could be able to analyze the samples;

- Evaluation of the panel performance - after training, the assessors were evaluated as regards their ability to discriminate samples and repeatability or reliability (the ability to reproduce results). Two-way Analysis of Variance (ANOVA) was performed on the data obtained for each sensory attribute using two causes of variation (sample and repetition). The selected judges were those with $\mathrm{p}<0.30$ for the cause of variation "sample" and $p>0.05$ for the cause of variation "repetition" (DAMÁSIO; COSTELL, 1991). All analyses were performed using XLSTAT software (2005);

- Multiple Comparison Test - after the identification of the attributes used for describing the appearance and flavor of the fruits, the samples were analyzed using the Multiple Comparison Test (MEILGAARD; CIVILLE; CARR, 1999). The Multiple Comparison Test allows verifying whether the papayas treated with different coatings and concentrations significantly differed from the reference sample (without coating) in terms of appearance and flavor, and also estimates the degree of such differences.

Seven fruits (one per treatment) were coded with three-digit numbers and presented to judges in individual sensory booths at the Sensory and Instrumental Evaluation Laboratory of the Embrapa Food Technology, Rio de Janeiro - RJ. The assessors received the reference sample $(\mathrm{R})$ codified as such and also codified with a three-digit number (blind reference), similarly to the other experimental samples. The inclusion of the blind reference as a sample can be useful to check the panel performance since no difference between the coded reference and the sample $\mathrm{R}$ was expected. The assessors were requested to compare each sample with the reference (R) and evaluate it in terms of each sensory attribute to check whether the perceived intensity was higher, equal, or lower than R. When the intensity was considered higher or lower than the reference, they were asked to indicate the amount of difference on a nine-point scale, which varied from 1 : less intense than R; 5: equal to R; and 9: more intense than R. The same process was repeated for the 13 investigated sensory attributes with repetition, i.e. the samples were evaluated twice (one session in the morning and another in the afternoon) by the sensory panel. Panelists received the same fruits (whole papaya) for the two evaluations when assessing appearance attributes, although codified with different numbers.

The first evaluation occurred four days after the application of the coating. The evaluation of the appearance attributes was carried out by nine selected and trained judges on days $4,6,8$, 12 and 14, whereas of the flavor attributes were carried out at the $8^{\text {th }}, 12^{\text {th }}$ and $14^{\text {th }}$ day of storage. The evaluation of the flavor attributes began at the $8^{\text {th }}$ day of storage because before that 
the fruits were not mature enough for consumption. For the evaluation of the flavor attributes, the seven different samples (six experimental + control) were longitudinally sliced and presented in white plastic plates coded with three digit numbers. The order of the sample presentation was balanced during the entire study. Mineral water and water biscuit were used for cleansing the palate between samples.

The data were analyzed using analysis of variance (ANOVA), and the samples and days of storage were considered as causes of variation. The Dunnett's test was used to check the difference between the reference sample $(\mathrm{R})$ and the experimental samples using the score 5 (no different from $\mathrm{R}$ ) as the reference sample. All analyses were carried out using the XLSTAT - MX software (2005).

\section{Results and discussion}

Table 1 presents the attributes evaluated by the sensory panel as well their definitions. The judges used 13 sensory attributes to describe the fruits; nine for appearance (green color, yellow color, orange color, color uniformity, brightness, fungus presence, injury, surface smoothness, and film integrity) and four for flavor (characteristic, unripe fruit, bitter taste, and sweet taste).

\subsection{Performance of the sensory panel}

For the appearance attributes at the $4^{\text {th }}$ day of storage (first day of evaluation), seven assessors did not perceive any difference between the experimental samples and the Reference (R) in terms of color uniformity, fungi presence, green and yellow color, surface smoothness, film integrity, brightness, and damage. However, it would be expected to find small differences between the fruits, mainly in relation to color since the change from green to yellowish is derived from the process of ripening, which occurred along the storage period. With regard to the repeatability of the assessors in the same period of analysis, it was observed that three judges detected differences for the following color attributes: uniformity, orange, green, and yellow color between repetitions, thus suggesting that it would have been necessary to have trained the panel better. Nonetheless, the issue concerning repeatability can be explained not only by the difficulty of standardizing the samples at the beginning of the experiment but also by the variability of the fruits.

With regard to the fungi presence, there were no signs of decay or damage during this period. The attributes surface smoothness, film integrity, and brightness were considered inherent to the coating and were not detectable during this evaluation. On the subsequent days, the number of assessors who did not identify differences between samples decreased from six to four as a consequence of more evident differences due to the increased number of storage days and to the different coatings.

\subsection{Multiple comparison test}

\section{Attributes of appearance}

Figures $1 \mathrm{a}, \mathrm{b}$, and $\mathrm{c}$ show the results of the Multiple Comparison Test for the color attributes: green, yellow, and orange, respectively. There was significant difference $(\mathrm{p}<0.05)$ between the coated fruits and the reference sample $(\mathrm{R})$ in terms of skin color during all evaluations. The use of Cassava Starch (CS) (3 and 5\%) and the Carboxymethyl Starch (CMS) (5\%) coatings, except for the $6^{\text {th }}$ day of storage, resulted in greener fruits on all days of evaluation. The CMS coating at $3 \%$ maintained a more intense green color on the last three days of the evaluation.

The development of the yellow color was lower in the coated fruits with highest concentrations in relation to the reference during all storage days. The blind reference and the papayas coated with the cassava starch at 1,3 , and $5 \%$ as well as the CMS at 3 and 5\% maintained a lighter yellow colorcolor than $\mathrm{R}$ until day $12^{\text {th }}$ of storage. In general, the coatings delayed the orange skin pigmentation, but with the CMS coating at $1 \%$ the fruits presented a similar reference tendency. Papayas coated at $5 \%$ maintained a lighter orange during all storage period. Pereira et al. (2006) observed that the coatings of cassava starch at 1 and 3\% delayed the development of that pigmentation in four days in relation to the control. The change in the papaya skin color from green to yellow-orange is due

Table 1. Sensory attributes of papaya coated with different coatings and respective definitions given by the sensory panel.

\begin{tabular}{|c|c|}
\hline Attribute & Definition \\
\hline \multicolumn{2}{|l|}{ Appearance } \\
\hline Green color & Visual perception of the green color in the skin of the fruits \\
\hline Yellow color & Visual perception of the yellow color in the skin of the fruits \\
\hline Orange color & Visual perception of the orange color in the skin of the fruits \\
\hline Color uniformity & Color of the skin without spots or differentiated marks \\
\hline Brightness & Non-opaque aspect observed on the surface of fruits \\
\hline Fungi presence & Presence of rot, moulds of different colors \\
\hline Injury & Damage on the surface of fruits \\
\hline Surface smoothness & Skin without a shriveled aspect \\
\hline Coating integrity & Absence of coating peeling \\
\hline \multicolumn{2}{|l|}{ Flavor } \\
\hline Characteristic flavor & Characteristic flavor expected for a ripe papaya \\
\hline Unripe fruit flavor & Flavor of unripe fruit \\
\hline Bitter taste & Perception of bitterness due to less intensity of sweetness \\
\hline Sweet taste & Perceived sweetness typical of the ripe fruit \\
\hline
\end{tabular}


Green color
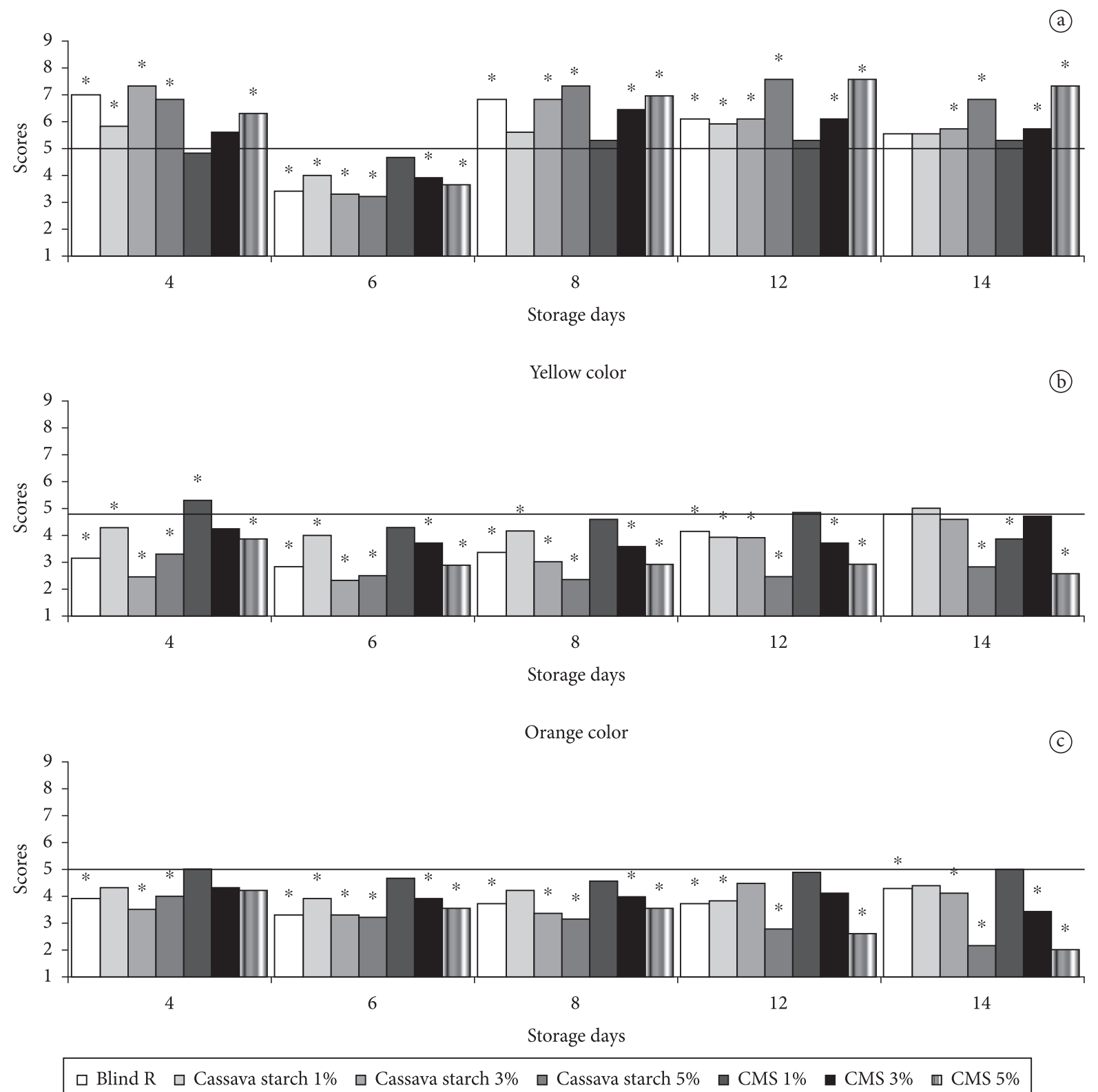

Figure 1. Results of the Multiple Comparison Test for the attributes: a) green color; b) yellow color, and c) orange color of papaya coated with cassava starch and CMS. ${ }^{\star}$ Mean scores significantly different from reference sample (shown by the black line starting on the score 5) by the Dunnett's test at $5 \%$.

to the chlorophyll destruction of the epidermic tissue and to the increase in the carotenoids content. The chlorophyllase's activity increases with the ripening. The observed tendency of the green color retention in the fruits indicates a delay in the process of ripening, which is related to the respiratory rate and ethylene production. The sharp increase in climacteric ethylene production at the onset of ripening is considered to be the initiator of changes in color, texture, aroma, flavor, and other biochemical and physiological attributes (YANG; HOFFMAM, 1984; BRADY, 1987; OETIKER; YANG, 1995). The ethylene $\left(\mathrm{C}_{2} \mathrm{H}_{4}\right)$ is involved in the ripening acceleration and senescence of climacteric fruits (JACOMINO et al., 2002) such as papaya. According to Manica, Martins and Ventura (2006) during the period of the skin color change, the respiratory rate of the fruit quickly increases, and it achieves the maximum of plain maturation. The effect of the modified atmosphere provided by the coating, which altered the gas composition $\left(\mathrm{CO}_{2}\right.$ and $\left.\mathrm{O}_{2}\right)$, can be responsible for the reduction of the respiratory process and the fruits' autocatalytic ethylene production, mainly when used in higher concentrations since higher concentrations will form thicker films on the fruits' epidermis.

Considering the attribute color uniformity, a significant difference was observed between the fruits during storage. Figure 2a shows that at the day 4 , the fruits coated with cassava starch at 3 and 5\%, as well those coated with CMS at 5\%, presented a more uniform coloration than the reference. On the other hand, those with both coating at 1\% and CMS at 3\% were very similar to the reference. It was observed that the coded reference was considered more uniform than the reference 

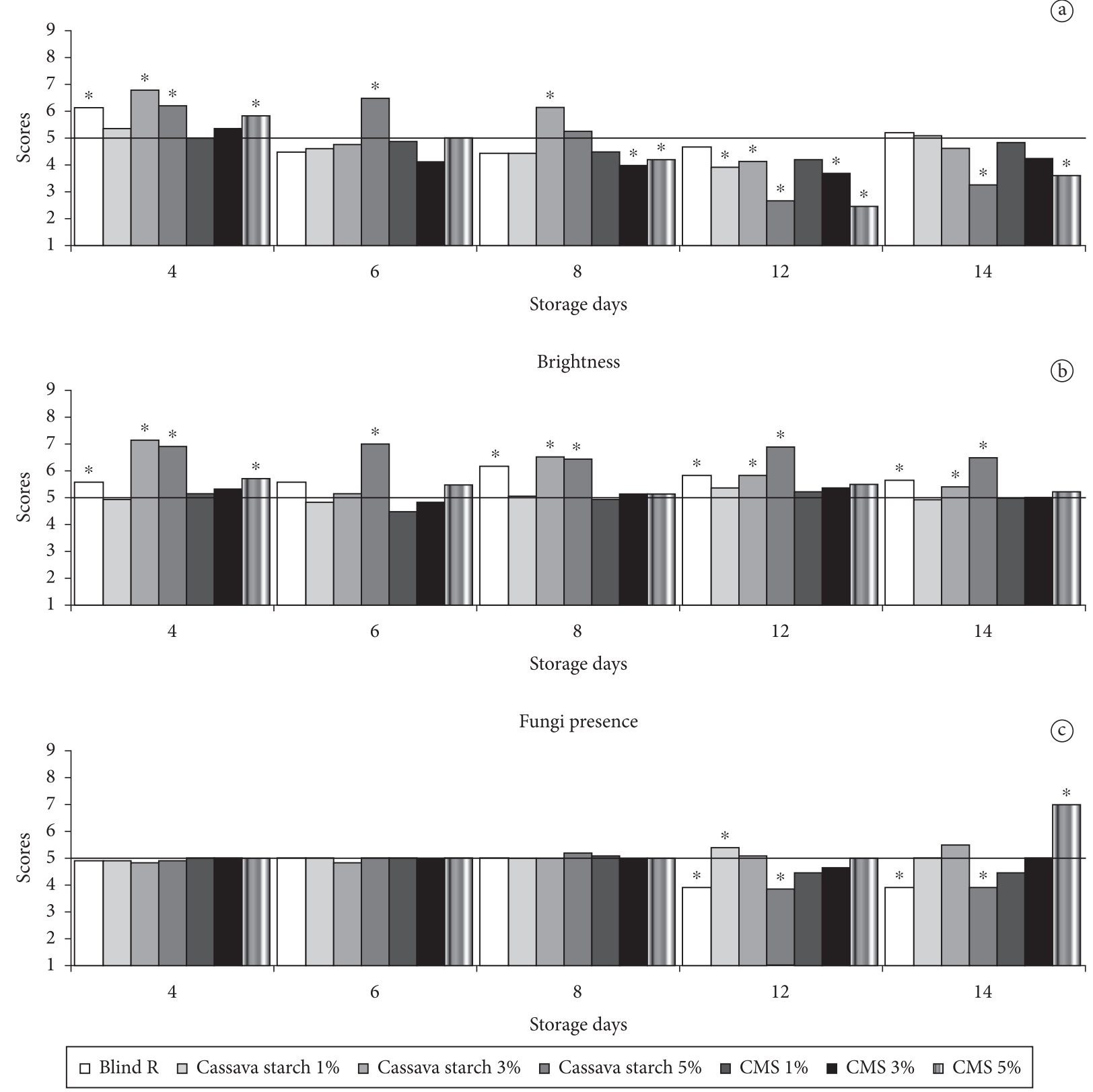

Figure 2. Results of the Multiple Comparison Test for the attributes: a) color uniformity; b) brightness, and c) fungi presence of papaya coated with cassava starch and CMS. ${ }^{\star}$ Mean scores significantly different from reference sample (shown by the black line starting on the score 5) by the Dunnett's test at $5 \%$.

presented as such, i.e coded with $\mathrm{R}$, thus revealing the difficulty of working with this type of raw material, which is not uniform in relation to maturation.

On day 6 of storage, all fruits were very similar to the reference in relation to color uniformity, except for those with the cassava starch at 5\%. Up to the day 8, the CS coatings at 5\% and CMS at 3 and $5 \%$ caused less uniformity to the fruits. On day 12 , except for the control fruits and those with CMS at $1 \%$, all fruits presented a less uniform coloration than the reference, and on day 14 , only the fruits at $5 \%$ (CS and CMS) were considered to be less uniform in relation to color by the sensory panel. Despite the highest concentrations, the coatings helped to keep the fruits' greener coloration (Figure 1a); such concentrations caused a non-uniformity of color, mainly on the last days of storage, which can be an unfavorable characteristic for the fruits commercialization since it worsens their appearance. Taking into account the ripening physiology, one can say that depending on the relative $\mathrm{CO}_{2}, \mathrm{O}_{2}$, and ethylene concentrations the ticker coating contributed to a slowed ripening and consequent maintenance of the green colour. However, the thickness of the coating cannot provide anaerobic respiration, which will undermine the quality of fruits. Tanada-Palmu and Grosso (2005) investigated the effect of gluten based-coatings on the extension of the shelf life of strawberries and reported that consumers rejected the fruits coated with bi-layers (formulation 
of gluten + composed formulation) on every test. Such result was a consequence of the artificial and opaque coloration together with the waxed appearance of the fruits, which hindered the natural coloration of the strawberries. On the other hand, the composed coating and the gluten basis kept the visual quality of the fruits during all storage period.

The brightness perception by the trained panel was significantly different among fruits during the storage period (Figure $2 \mathrm{~b}$ ). During storage, fruits coated with cassava starch at $5 \%$ were considered brighter by the sensory panel, when compared with the reference. Occasionally, the coatings at $3 \%$ also presented this characteristic. The fruits treated with CMS and the film of cassava starch at $1 \%$ did not confer more brightness to the fruits; thus they did not differ from the reference on most of the storage period. The characteristic of providing brightness to the fruits seems to be related to the cassava starch coating basis at the concentrations of 3 and $5 \%$ since the coatings of modified starch kept the fruits similar to the reference. Fakhouri et al. (2007) evaluated the effect of the association of gelatin with suspensions of wheat native starch, sorghum, and potato on Crimson grapes. The results for overall appearance, color, brightness and intention of purchase of the fruits with coating were higher in relation to the control (without coating).

Regarding the fungi presence attribute, the fruits with cassava starch at $5 \%$ presented less decayed than the reference on day 12 , and they remained like this up to the day 14 (Figure 2c). Papayas coated with modified starch (CMS) at $5 \%$ presented a higher intensity of fungi (moderate, according to the used scale) on day 14, and they were also more injured (Figure 3a). Although these coatings were made by carbohydrates, under the conditions of the present study they did not favor the development of fungi (except to CMS $5 \%$ on the $14^{\text {th }}$ day) since the fruits were equal to those without coatings in most of the time. Coatings made of cellulose and carnauba wax were used by Baldwin et al. (1999) in mangos. The authors verified that probably they had functioned as a physical barrier for the development of pathogens since losses due to fungi were lower in the coated fruits.

It was observed that the coatings significantly affected the presence of injuries. The fruits coated with cassava starch at $5 \%$ and the control samples were less damaged on the $4^{\text {th }}$ and $8^{\text {th }}$ days of storage (Figure 3a). On days 12 and 14, the cassava starch at $3 \%$ as well those of CMS at $5 \%$ provided higher mean scores (6 and 7, respectively), which corresponded to median and moderately more injured fruits than the reference. The majority of the treatments presented fruits either less injured than $\mathrm{R}$ or with no differences to R. Coatings of cassava starch at 2 and $3 \%$ provided a better appearance and longevity to mangos (SCANAVACA JÚNIOR; FONSECA; PEREIRA, 2007).

There was a significant difference for the attribute surface smoothness during storage. The coating of cassava starch at $5 \%$ made the surface of the fruits smoother than those without coating on all days of evaluation (Figure $3 \mathrm{~b}$ ). When used at 3\%, this characteristic was only observed on days 4 and 8 . Fruits having the CMS appeared always very similar to the reference, that is, such materials did not influence the attribute surface smoothness. The referred attribute was defined as skin without a shriveled aspect (Table 1), which greatly affects the product visual quality, damages the appearance and negatively impacts on the consumer intention to purchase. Some authors such as Fakhouri and Grosso (2003) and Tanada-palmu and Grosso (2005) evaluated the overall appearance and the intention to purchase of guavas and strawberries coated with gelatin, triacetin, lauric acid, and wheat gluten-based. They reported that the fruits had good acceptance by consumers during the experimental period suggesting the adequacy of the coatings.

For the sensory attribute coating integrity, a significant difference was observed between the treatments and storage days. The coating of cassava starch at $5 \%$ provided a higher integrity than the reference $(\mathrm{p}<0.05)$ only on day 6 . However, on the other days, it was not observed (Figure 3c). Despite the fact that the reference does not have a coating, this characteristic of less integrity can be explained by the peeling in the surface of the fruits. Modified starch and cassava starch at $1 \%$ provided better coating during all storage periods since the fruits remained similar to the reference, suggesting that these materials did not damage the appearance of the papayas. The peeling observed by assessors in the fruits with cassava starch at $5 \%$ occurred in most part of the storage period (except on day 6), and it compromised their visual appearance (not expected for the product), according to the sensory panel. This concentration of starch formed a denser coating, which can be related to a more intense peeling.

According to Viña et al. (2007) peeling is possibly related to the coating dehydration. The coating integrity is a critical factor related to adhesion and flexibility, characteristics which are incompatible with the irregular shape of most vegetables. The same authors verified that the addition of plastifying substances and lipids to the suspensions of corn starch led to a decrease in the apparent viscosity improving the flexibility by the reduction of the interactions in the polymeric chain.

\section{Attributes of flavor}

There was a significant difference for the attribute characteristic flavor on days 12 and 14 of storage. The fruits did not alter the characteristic papaya flavor on day 8 . On day 12 , the fruits coated with cassava starch and CMS, both at $5 \%$ had a less characteristic flavor than the fruits without coatings (control) (Figure 4a). This tendency was kept in the papayas coated with modified starch at $5 \%$, and also in the fruits with cassava starch at $1 \%$ up to day 14 . The decrease in the characteristic flavor in fruits with modified starch at $5 \%$ can be related to the bitter taste, which was also detected in those fruits at the same storage time (Figure 4c). The characteristic papaya flavor is achieved during the ripening process, when a decrease in acidity and increase in sweetness occurs. However, the coatings can affect the natural ripening and postpone for a few days the maxima climacteric respiration that takes place after the harvest. This means that fruits coated with ticker layers may become palatable later than those uncoated or coated with thinner layers, i.e. without physical barriers to the natural gas exchanges that occur during the ripening physiology. It shall be taken into account that there is a maximum limit necessary for the presence of $\mathrm{O}_{2}$, below 

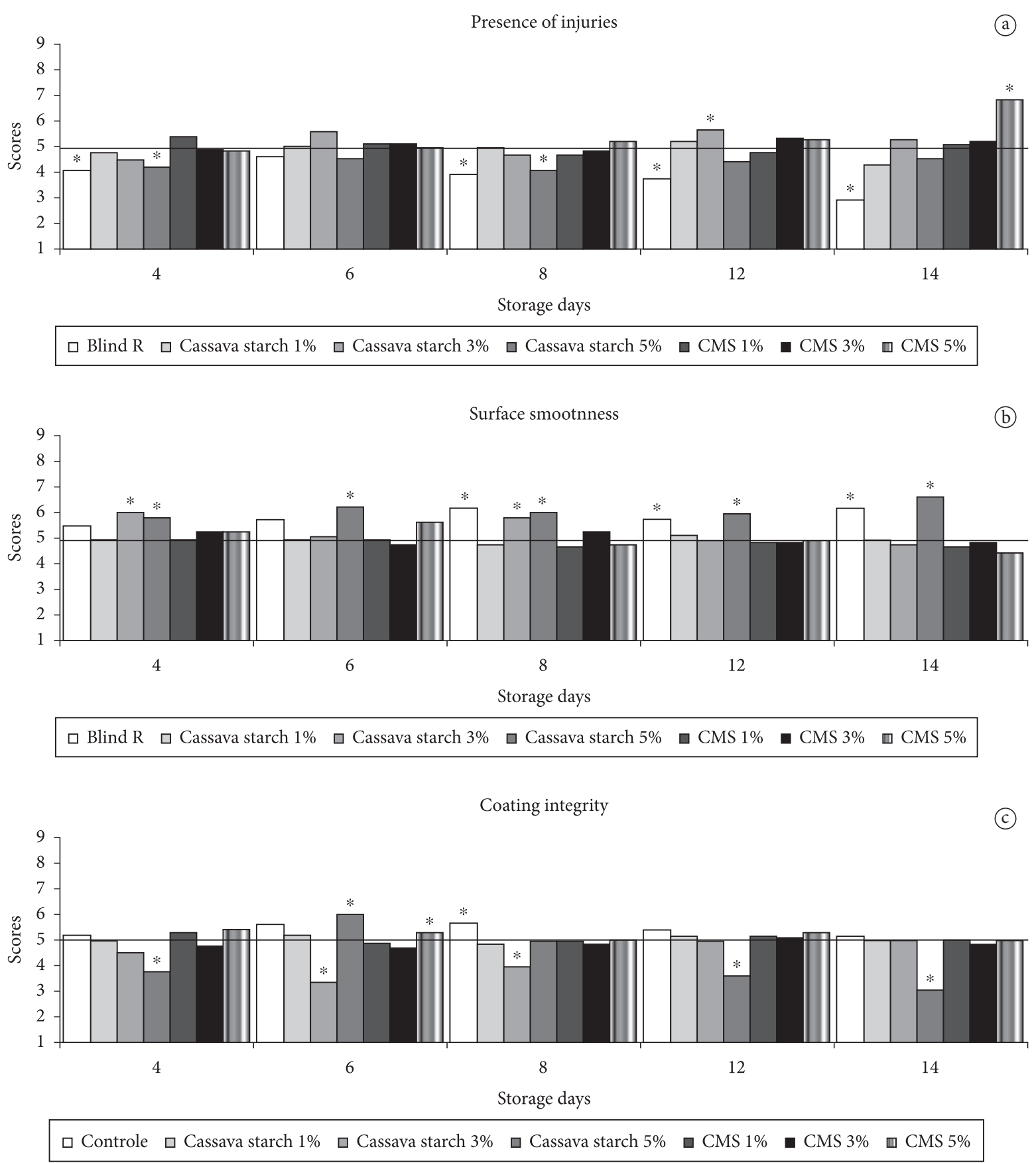

Figure 3. Results of the Multiple Comparison Test for the attributes: a) presence of injury; b) surface smoothness, and c) coating integrity of papaya coated with cassava starch and CMS. ${ }^{\star}$ Mean scores significantly different from reference sample (shown by the black line starting on the score 5) by the Dunnett's test at $5 \%$.

which anaerobiosis occurs with accumulation of products of fermentation, in addition to a development of odd flavor, and a degradation of tissues as well (BANKS; DADZIE; CLELAND, 1993). This could have taken place with the Coating of Modified Starch (CMS) at 5\% (days 12 and 14) and with the coating of cassava starch at $1 \%$ on day 14 . Nonetheless, alterations in flavor are not always detected when edible coatings are used. Fakhouri et al. (2007) reported that coating made of native starches and gelatin did not alter the flavor of grapes in relation to control, suggesting that the coatings did not affect the sensory properties of the fruit.
Considering the attribute flavor of unripe fruit, the results revealed that there was no significant difference in the evaluated fruits in any of the storage days. Despite the interference of the coatings on the process of the papaya ripening evidenced by the retention of the green color (Figures $1 \mathrm{a}, \mathrm{b}$ and $\mathrm{c}$ ), such coatings did not favor the perception of the unripe flavor since the samples were all similar to the reference (which was ripened without coating, Figure $4 \mathrm{~b}$. The exposure of fruits to low concentrations of $\mathrm{O}_{2}$ and high concentrations of $\mathrm{CO}_{2}$ can lead to anaerobiotic respiration and physiological injuries, which result in undesirable alterations in color, aroma, and flavor (VILAS BOAS, 1999). In the 

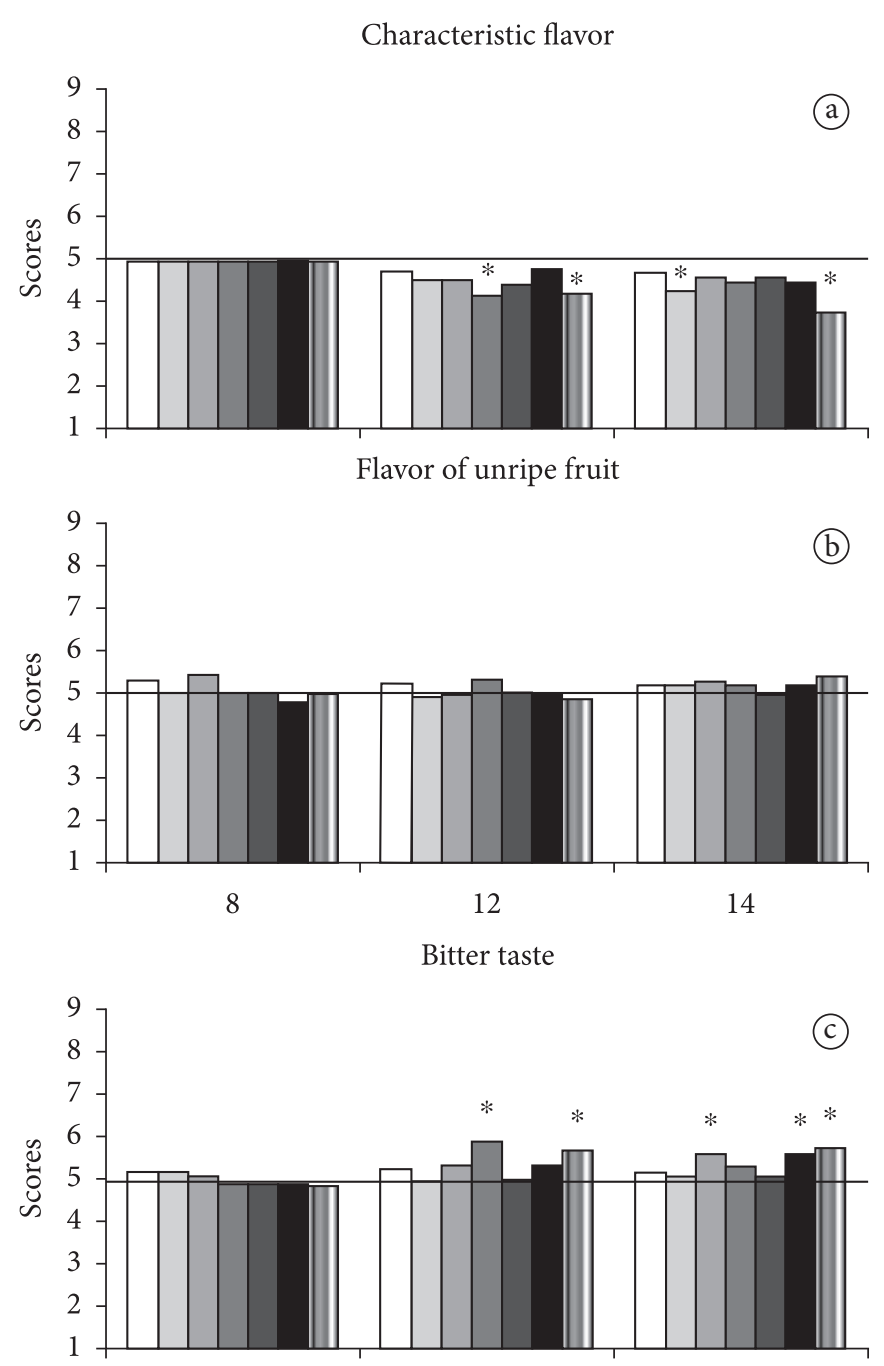

8

12

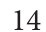

Storage days

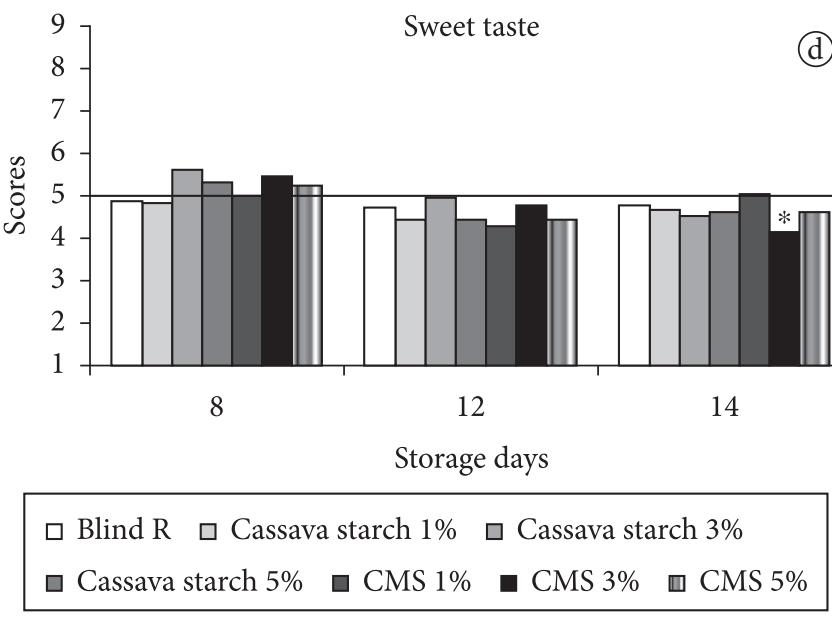

Figure 4. Results of the Multiple Comparison Test for the attributes: a) characteristic flavor; b) flavor of unripe fruit; c) bitter taste, and d) sweet taste of papaya coated with cassava starch and CMS. ${ }^{*}$ Mean scores significantly different from reference sample (shown by the black line starting on the score 5) by the Dunnett's test at $5 \%$. present study, the coating did not lead to the flavor of the unripe fruit during storage, thus suggesting that the gas exchanges were enough to not allow anaerobiosis, which is very harmful to the flavor of the fruit. Similar tendency was observed in the reference sample (no coating).

It was observed that from day 12 there was significant difference among the coatings for the attribute bitter taste. Hence, bitter taste was detected in fruits coated with starch and CMS at $5 \%$ on the $12^{\text {th }}$ day of storage (Figure $4 \mathrm{c}$ ). On day 14 , this characteristic was observed in the fruits with cassava starch at 3\%, and with CMS at 3 and 5\%. According to Fontes, Sarmento and Spoto (2007), the judges did not detect bitter taste in minimally processed apples with preserving solution and coating.

The intensity of the attribute sweet taste was not altered by the coating according to the sensory panel. Such result explains the scores, always significantly equal to five, which corresponds to no differences in relation to the reference (Figure 4d). However, on day 14, the fruits with CMS at 3\% received the average score of 4.2 , which corresponds to fruits slightly less sweet than the reference. Similarly, Fontes, Sarmento and Spoto (2007) did not observe any alteration in the sweet taste in minimally processed apples after coating with cassava starch at $5.5 \%$.

\section{Conclusions}

The results of the present study allowed the following conclusions:

The attributes of appearance were more affected by the cassava starch and carboxymethyl starch (CMS) coatings than the flavor attributes. Coatings at the concentrations of 3 and $5 \%$ kept green color.

The coating of cassava starch at $5 \%$ was more adequate to the fruits considering the majority of the investigated attributes of appearance. However, the peeling, which was evidenced by the lower skin integrity, was considered inadequate to the papayas.

\section{Acknowledgements}

The authors are grateful to GAIA Importações e Exportações Business Company for supplying the fruits and to Fundação Carlos Chagas Filho de Amparo à Pesquisa do Rio de Janeiro/ FAPERJ for the financial support provided (research scholarship granted to the first author).

\section{References}

AGRIANUAL 2011: Anuário da Agricultura Brasileira. São Paulo: FNP Consultoria \& AgroInformativos, 2011.

ARRUDA, M. C. et al. Conservação de raízes de beterraba cv. early wonder sob atmosfera modificada. Revista Brasileira de Agrociência, v. 10, n. 2, p. 255-257, 2004.

BALDWIN, E. A. et al. Effect of edible coatings with different permeability characteristics on mango (Mangifera indica L.) ripening during storage. Postharvest Biology and Techonology, v. 17 , n. 17 , p. $215-226,1999$. http://dx.doi.org/10.1016/S09255214(99)00053-8 
BANKS, N. H.; DADZIE, B. K.; CLELAND, D. J. Reducing gas exchange of fruits with surface coatings. Postharvest Biology and Technology, v. 3, n. 3, p. 269-284, 1993. http://dx.doi. org/10.1016/0925-5214(93)90062-8

BOTREL, D. A. et al. Revestimento ativo de amido na conservação pós-colheita de pera Williams minimamente processada. Ciência Rural, v. 40, n. 8, p. 1814-1820, 2010. http://dx.doi.org/10.1590/ S0103-84782010000800023

BRADY, C. J. Fruit ripening. Annual Review of plant physiology and plant molecular biology, v. 38, p. 155-178, 1987. http://dx.doi. org/10.1146/annurev.arplant.38.1.155

DAMÁSIO, M. H.; COSTELL, E. Análisis sensorial descriptivo: Generación de descriptores y selección de catadores. Revista Agroquímica de Tecnologia de Alimentos, v. 31, n. 2, p. $165-178,1991$.

FAKHOURI, F. M. et al. Coatinges e coberturas comestíveis compostas à base de amidos nativos e gelatina na conservação e aceitação sensorial de uvas Crimson. Ciência e Tecnologia de Alimentos, v. 27, n. 2, p. $369-375,2007$. http://dx.doi.org/10.1590/S010120612007000200027

FAKHOURI, F. M.; GROSSO, C. Efeito de coberturas comestíveis na vida útil de goiabas in natura (Psidium guajava L.) mantidas sob refrigeração. Brazilian Journal of Food Technology, v. 6, n. 2, p. 203-211, 2003.

FONTES, L. C. B.; SARMENTO, S. B. S.; SPOTO, M. H. F. Características sensoriais e microbiológicas de maçãs minimamente processadas recobertas com películas. Ciência e Tecnologia de Alimentos, v. 27, n. 1, p. 91-98, 2007. http://dx.doi.org/10.1590/ S0101-20612007000100016

HENRIQUE, C. M. Utilização do ethephon e da película de fécula de mandioca na conservação pós-colheita de limão Siciliano (Citrus limon (Linn) Burn). 1999. 161 f. Dissertação (Mestrado em Agronomia/Horticultura) - Faculdade de Ciências Agronômicas, Universidade Estadual Paulista, Botucatu, 1999.

HENRIQUE, C. M. Caracterização de filmes de féculas modificadas de mandioca como subsídios para aplicação em pós-colheita de hortícolas. 2002. 139f. Tese (Doutorado em Agronomia/ Horticultura)-Faculdade de Ciências Agronômicas, Universidade Estadual Paulista, Botucatu, 2002.

HENRIQUE, C. M.; EVANGELISTA, R. M. Processamento mínimo de cenouras orgânicas com uso de películas biodegradáveis. Publicações UEPG Ciências Exatas e da Terra, Ciências Agrárias e Engenharia, v. 12, n. 3, p. 7-14, 2006.

HOA, T. T.; DUCAMP, M. N. Effects of different coatings on biochemical changes of 'cat Hoa loc' mangoes in storage. Research Note.
Postharvest Biology and Technology, v. 48, n. 1, p. 150-152, 2008. http://dx.doi.org/10.1016/j.postharvbio.2007.09.021

JACOMINO, A. P. et al. Amadurecimento e senescência de mamão com 1-metilciclopropeno. Scientia Agrícola, v. 59, n. 2, p. 303-308, 2002. http://dx.doi.org/10.1590/S0103-90162002000200015

MANICA, I.; MARTINS, D. S.; VENTURA, J. A. Taxonomia, morfologia e anatomia. In: MANICA, I. (Ed.). Mamão: tecnologia de produção, pós-colheita, exportação, mercados. Porto Alegre: Cinco Continentes, 2006. cap. 2, p. 19-32.

MEILGAARD, M.; CIVILLE, G. V.; CARR, B. T. Sensory Evaluation Techniques. 3. ed. New York: Boca Raton, 1999. 354 p.

OETIKER, J. H.; YANG, S. F. The role of ethylene in fruit ripening. Acta Horticulturae, v. 398, p. 167-178, 1995.

OLIVEIRA JÚNIOR, L. F. G.; COELHO, E. M.; COELHO, F. C. Caracterização pós-colheita de mamão armazenado em atmosfera modificada. Revista Brasileira de Engenharia Agrícola e Ambiental, v. 10, n. 3, p. 660-664, 2006.

PEREIRA, M. E. C. et al. Amadurecimento de mamão formosa com revestimento comestível à base de fécula de mandioca. Ciência e Agrotecnologia, v. 30, n. 6, p. 1116-1119, 2006. http://dx.doi. org/10.1590/S1413-70542006000600011

REIS, K. C. et al. Pepino japonês (Cucumis sativus L.) submetido ao tratamento com fécula de mandioca. Ciência e Agrotecnologia, v. 30, n. 3, p. 487-493, 2006. http://dx.doi.org/10.1590/S141370542006000300015

SCANAVACA JÚNIOR, L.; FONSECA, N.; PEREIRA, M. E. C. Uso de fécula de mandioca na pós-colheita de manga 'surpresa'. Revista Brasileira de Fruticultura, v. 29, n. 1, p. 67-71, 2007.

TANADA-PALMU, P. S.; GROSSO, C. R. F. Effect of edible wheat gluten-based coating and coatings on refrigerated strawberry (Fragaria ananassa) quality. Postharvest Biology and Technology, v. 36, n. 2, p. 199-208, 2005. http://dx.doi.org/10.1016/j. postharvbio.2004.12.003

VILAS BOAS, E. V. B. Aspectos fisiológicos do desenvolvimento de frutos. Lavras: UFLA/FAEPE/DCA, 1999.

VIÑA, S. Z. et al. Effects of polyvinylchloride coating and edible starch coatings on quality aspects of refrigerated Brussels sprouts. Food Chemistry, v. 103, n. 3, p. 701-709, 2007. http://dx.doi. org/10.1016/j.foodchem.2006.09.010

YANG, S. F.; HOFFIMAN, N. E. Ethylene biosynthesis and its regulation in higher plants. Annual Review of Plant Physiology, v. 35 , p. $155-189,1984$. http://dx.doi.org/10.1146/annurev. pp.35.060184.001103

XLSTAT-MX. Paris: Addinsoft, 2005. 